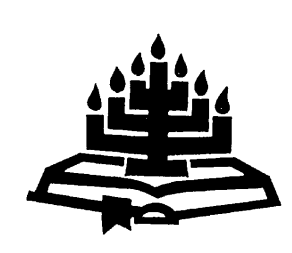

\title{
'n Aanvullende formulier gefokus op die verhouding tussen Pasga en die nagmaal
}

\author{
B.J. de Klerk \\ Skool vir Kerkwetenskappe \\ Potchefstroomkampus \\ Noordwes-Universiteit \\ POTCHEFSTROOM \\ E-pos: ben.deklerk@nwu.ac.za
}

\section{Abstract \\ A supplementary formulary focused on the relation between Passover and Holy Communion}

Can a supplementary formulary that especially focuses on the relation between Passover and Holy Communion enrich the celebration of Holy Communion? After an investigation into the course of events during Passover and the two moments Jesus links up with during the institution of Holy Communion, the researcher found that the following aspects can at least add to the meaning and experience of the celebration. During the eating of the bread (at Passover: the bread of sorrow), the participant is guided to think of and experience the sorrow of slavery to sin and to consciously surrender this guilt to Christ. The believer directly receives the assurance of the forgiveness of sins. During the drinking of the cup of thanksgiving the believer experiences the festive joy of redemption and reconciliation, and consequently feels a new beginning breaking through. This urges the believer to purify his/her life from the old sinful habits (the old yeast) as the result and consequence of the celebration of the Communion. The Communion should, due to its unique eschatological perspective (in contradiction to Passover) have the effect that the death of Christ is proclaimed in the daily life of the believer until He comes. An example of such a possible supplementary formulary is included.

\section{Opsomming}

'n Aanvullende formulier gefokus op die verhouding tussen Pasga en die nagmaal

Kan 'n aanvullende formulier wat veral fokus op die verhouding tussen Pasga en die nagmaal deelname aan nagmaalsvierings 
verryk? Nadat die verloop van die Pasga asook die twee momente waarby Jesus by die instelling van die nagmaal aangesluit het, nagegaan is, is bevind dat die volgende aspekte minstens die betekenis en belewing van die viering kan aanvul. By die eet van die brood (Pasga: die brood van smarte) dink en beleef die deelnemer aan die nagmaal die smart van die slawerny van die sonde en gee doelbewus hierdie skuld aan Christus af en ontvang regstreeks die versekering van vergewing van sonde. By die drink van die beker van danksegging beleef die gelowige dat die feesvreugde van verlossing en versoening, dus 'n nuwe begin, 'n deurbraak. Dit vra dat die lewe gesuiwer moet word van die ou sondige gewoontes (die ou suurdeeg) as die resultaat en uitwerking van die viering van die nagmaal. Die nagmaal moet, weens sy unieke eskatologiese perspektief (in teenstelling met die Pasga) die uitwerking hê dat die dood van Christus in die daaglikse lewe verkondig word totdat Hy kom. 'n Voorbeeld van so 'n moontlike aanvullende formulier word inges/uit.

\section{Inleiding}

Welker (2000:5) vra die belangrike vraag: "Why is it appropriate to call Holy Communion 'source and summit of the church's life'?" Hy beantwoord die vraag soos volg:

Because: In the Lord's Supper the risen and exalted Christ is present. Holy Communion focuses us on the reality of the resurrected Jesus Christ and helps us to perceive this reality. (Welker, 2000:10.)

Die nagmaal laat deelnemers 'n handeling verrig waarin hulle die opgestane en verheerlikte Christus se teenwoordigheid met al hulle sintuie kan beleef. "At the same time the limits of merely sensuous experience are consciously noted." (Welker, 2000:18.) Die nagmaal vorm die kerk, omdat Christus teenwoordig is by die maaltyd deur sy Gees. Daarom word die kerk, soos die apostels (Hand. 4:13), verander deur die gemeenskap met haar Bruidegom. Die nagmaal maak die kerk kerk, omdat die gemeenskap wat in die nagmaal plaasvind, die kerk na die beeld van Christus vorm (Leithart, 2000: 185).

Die belang van die nagmaal kan met die volgende stellings aangedui word: 'n kerk wat feesvier met wyn word gevorm tot 'n vreugdevolle gemeenskap; 'n kerk wat die gemeenskaplike maaltyd geniet, word in een liggaam gebind en sal die verwoestende effek van individualisme kan weerstaan; ' $n$ kerk wat brood deel aan die tafel van 
die Here, leer die waardes van vrygewigheid en nederigheid; 'n kerk wat die Here se dood verkondig in die nagmaal, beoefen selfopoffering en word immuun teen selftevredenheid en dra tegelyk die evangelie vrymoedig uit. "Not automatically, but in the context of biblical teaching and a robust community life, the skills and virtues practiced at the Lord's table will spill over to fill the whole church with an eucharistic ethos." (Leithart, 2000:185.) In sy wysheid het Christus die nagmaal ingestel en bepeinsing en navorsing oor die plek en krag van die nagmaal in die lewe van die kerk van Christus sal voortduur.

Hierdie artikel poog om in die lig van bogenoemde ondersoek vas te stel of en hoedanig die nagmaalsviering verryk kan word deur ' $n$ aanvullende formulier wat op die verhouding tussen die Pasga en die nagmaal fokus. Die metode wat in hierdie ondersoek gevolg word, is 'n literatuurstudie, toegespits op afleidings vir die praktiese teologie op die terrein van die liturgiek.

\section{Aanvullende formuliere}

Tans word die 1563-formulier (ook in sy verkorte vorm), hoofsaaklik in reformatoriese kerke in Suid Afrika, veral in die Gereformeerde Kerke in Suid-Afrika (GKSA) gebruik. Dorn (2007:24) beskryf hierdie liturgiese formulier vir die nagmaal soos volg:

The liturgical form bears the stamp of the catechism in the structure, theological content, and even in the wording. The documentary evidence suggesting that this was deliberate in a letter dated 25 October, 1563, from Caspar Olevianus to Heinrich Bullinger.

Calvyn het 'n eie formulier opgestel in sy La forme des prieres wat in 1542 in Genève gepubliseer is. Dorn (2007:28) toon aan dat slegs sekere elemente hiervan in die 1563-formulier opgeneem is. Daar het dus tydens die sestiende-eeuse Reformasie meer as een formulier vir die nagmaal bestaan.

Naas die breedvoerige en verhelderende belydenis aangaande die nagmaal in die Heidelbergse Kategismus, word belanghebbende aanvullende aspekte van die nagmaal in Artikel 35 van die Nederlandse Geloofsbelydenis bely. Die Nederlandse Geloofbelydenis word die dogter van die Confessio Gallicana genoem en uit laasgenoemde, asook uit Guido de Brès se kontak met Calvyn, kan die invloed van Calvyn op die Nederlandse Geloofsbelydenis aangaande die nagmaal verklaar word (De Klerk, 1990:165). Die betrokke 
artikel 35 kom grootliks ooreen met dit wat Calvyn in sy Korte Kategismus oor die nagmaal leer en bely (Simpson, 1981:56-67). Waar die fokus in die Heidelbergse Kategismus op die anamnesis - die gedenk - val, word, aanvullend tot die Nederlandse Geloofsbelydenis, ook die eet en drink van die ware Christus met die Heilige Gees deur die geloof beklemtoon. In sy kommentaar op Johannes 6:35 verklaar Calvyn oor die "eet van die liggaam" en die "glo in Christus" soos volg:

Those who infer from this passage that to eat Christ is faith, and nothing else, reason inconclusively. I readily acknowledge that there is no other way in which we eat Christ than by believing; but the eating is the effect and fruit of faith rather than faith itself. For faith does not look at Christ only as at a distance, but embraces him, that he may become ours and may dwell in us. It causes us to be incorporated with him, to have life in communion with him, and, in short, to become one with him, (John $x v i i, 21)$. It is therefore true that by faith alone we eat Christ, provided we also understand in what manner faith unites us to him. (Calvin, 1959:159.)

Die feit dat daar in die belydenisskrifte aanvullend oor die nagmaal bely word, kan as grond vir meerdere formuliere dien.

In sy bespreking van die vier instellingsberigte in die sinoptici en by Paulus, noem Versteeg (1980:28) dat die nagmaal nie in een vorm nie, maar ten minste in twee vorms aan die kerk deurgegee is. Dit is volgens hom 'n baie sterk bewys dat die instellingswoorde, juis vanweë meerdere vorms, niks met magiese of towerformules te doen het nie. "Bij de avondsmaalberichten komen wij dan ook niets tegen van een krampachtig streven naar één vaste formulering." (Versteeg, 1980:28.) Die Heilige Gees het die instelling van die nagmaal in verskillende berigte laat opteken, soos wat dit in die sinoptiese evangelies en 1 Korintiërs 11 weergegee is. Die variasies in die vier instellingsberigte sluit enige suggestie uit dat dit magiese of towerformules kan wees. Vanuit hierdie hoek beskou, kan daar nie prinsipieel besware ingebring word teen ' $n$ aanvulling van die bestaande formulier wat verder op die verskillende kante van die nagmaal fokus nie. Uit die hoek van die waarde wat 'n formulier vir die onderrig en die verdieping in die deelname aan die nagmaal het, veral as gestreef word na 'n hoër frekwensie van nagmaalsviering, kan gekyk word na aspekte wat nuwe formuliere oplewer (vgl. Brienen, 1987: 214; Phillips, 2003:187). 


\section{Fokus op die verhouding tussen Pasga en nagmaal}

\subsection{Jesus stel die nagmaal in tydens die viering van die Pasga}

Oor die vraag of Jesus die nagmaal tydens die Pasga ingestel het, is daar verskillende standpunte. Lang (2008:239) is 'n verteenwoordiger van die een uiterste: die nagmaal ontstaan uit die Joodse offergedagte dat jy iets vir die Godheid gee en Hy jou dan daarvoor vergoed. Lang probeer ook aantoon dat die Joodse magiese ingesteldheid die basis vorm van die totstandkoming van die nagmaal. Hy redeneer op grond van sy interpretasie van 1 Korintiërs 10:1-4 dat, volgens Paulus, die beskouing van die gemeente was dat die nagmaalsbrood op 'n magiese wyse die Gees aan die deelnemers gee (Lang, 2008:247). Hy sê byvoorbeeld: "When a stronger partner (Christ) gives his blood in the form of wine to his weaker partner, the act of drinking forges a strong bond that can survive and even conquer death." (Lang, 2008:249; vgl. ook Mazza, 1999:25.)

Sommige wetenskaplikes gee toe dat die Pasga 'n soort agtergrond vir die nagmaal bied, maar stel dat dit onseker is of Jesus die nagmaal tydens die Pasga ingestel het. Die argumente wat aangevoer word, is dat daar verskille in die datering is tussen die sinoptici en Johannes (vgl. Dorn, 2007:129; Routledge, 2002:204). Tog bied Versteeg (1980:18, veral 35), Green (1999:159), Welker (2000:49), Phillips (2003:194) en Wandel (2006:10) oortuigende bewyse dat Jesus doelbewus die Pasga met sy dissipels as die geleentheid gekies het om die nagmaal in te stel. Wat by hierdie besondere laaste maaltyd saam met sy dissipels gebeur het en gesê is, is die mees bepalende vir die nagmaal van die kerk van alle tye (Versteeg, 1980:19).

\subsection{Die verloop van die Pasga}

Die Hebreeus vir Pasga is pesah en in Eksodus 12 word pesah parallel met abar gebruik, wat beteken "om verby te gaan" of "oor te slaan". "The Lord 'passed through' (abar) Egypt and in doing so 'passed over' (pasah) the blood marked houses." (Motyer, 2005: 140.)

Volgens die voorskrif van Eksodus 12:6-8 moes die Paasmaaltyd in die nag van 14/15 Nisan gehou word en volgens die sinoptici het die laaste Pasga op hierdie datum plaasgevind. "Pesah was a night ritual. It commended just before nightfall; it had to be completed and the remains to be burned before sunrise." (Segal, 1963:172.) Om te 
kan verstaan wanneer en op watter wyse Jesus die nagmaal ingestel het, is dit nodig om kortliks die verloop van die Pasga na te gaan. Die huisvader skink die eerste beker en prys die almagtige God vir die vrug van die wyn en spreek die seën daaroor uit (Kiddush). Daarna word uit die eerste beker gedrink (Theiss, 1994: 18). Die bitter kruie, wat simbool was van die bitter lyding in Egipte, word vervolgens geëet. Die verdrukking word nie net gesimboliseer nie, maar die huisvader kan dit ook vertel. Op die vraag van die jongste seun הסאה אלחאלאה אנאתחסי אמ (Wat onderskei hierdie nag van alle ander nagte?) word die verhaal van die nag van die uittog uit Egipte breedvoerig vertel (Routledge, 2002:213). Die verhaal word so vertel (haggadah) asof die huidige geslag werklik daardie nag aanwesig en betrokke was. Die verhaal word verder so vertel dat elke geslag verplig is om hulleself te sien asof hulle persoonlik uit Egipte getrek het (Witvliet, 2003:286). Na al die droefheid en smart wat hulle moes deurgaan, word die vreugde van verlossing nou beleef. Hierdie onderrig vorm 'n belangrike deel van die viering van die Pasga (Brumberg-Kraus, 1999:175). Met sy instellingswoorde laat Jesus ook die klem op onderrig val om die gebruik van die brood en wyn tydens die nagmaalsviering te verklaar.

Op hierdie stadium word 'n tweede beker wyn ingeskink en die seën daaroor uitgespreek, waarna die ongesuurde brood deur die huisvader gebreek en uitgedeel word. By die uitdeel daarvan klink die woorde: "Dit is die brood van ellende wat ons vaders in Egipte geëet het." (Versteeg, 1980:33.) In Deuteronomium 16:3 word die ongesuurde brood "die brood van smarte" genoem. Die volk moes die hele lam braai (teenoor heidenvolke wat rou vleis as ritueel geëet het) en dit saam met bitter kruie en ongesuurde brood eet. Hulle moes dit doen met hulle klere opgebind, met skoene aan en 'n staf in die hand. Dit wys op 'n spannende en vinnige vertrek. "Julle moet haastig eet." (Eks. 12:11.)

Motyer (2005:142) stel die volgende:

In haste: this word (found elsewhere only in Deut. 16:3 and Isa. $52: 12$ ) is hippazon from hapaz, 'to be in trepidation' and 'to hurry', with a focus sometimes on the former sometimes on the latter and sometimes on both (cf Deut. 20:3; 1 Sam. 23:26; 2 Sam. 4:4; 2 Kings 7:15; Ps. 31:22; 104:7).

Omdat die maaltyd heilig is, moet dít wat nie van die lam geëet is nie, verbrand word, want dit moet nie met hulle daaglikse voedsel vermeng word nie (Mathison, 2002:185). Die breek van die brood word deur die eintlike paasmaaltyd gevolg, naamlik die eet van die 
paaslam. Die lam herinner aan die lam wat geslag is en waarvan die bloed aan die deurkosyne gesmeer is. Daarna word die eerste deel van die Hallel (Ps. 113-114) antifonies gesing en die huisvader loof die Here, die Heerser in die wêreld wat die huidige geslag en die voorvaders uit Egipte gelei het (Theiss, 1994:22).

Die tweede fase van die maaltyd breek aan wanneer die derde beker rondgestuur word. Dit is genoem "die beker van lofprysing", na aanleiding van die belofte van God se redding met mag soos in Eksodus 6:6b beskryf (Routledge, 2002:219). Dit word veral ook "die beker van danksegging" genoem waartydens onder andere woorde gebruik is soos "Ons prys U Here ons God, Koning van die wêreld wat die hele wêreld voed met u goedheid, genade en liefde". Die drink uit die beker deur almal teenwoordig gaan daarom oor in die sing van die feeslied, die tweede helfte van die Hallel (Ps. 115-118) en dit loop uit op die groot hallel van Psalm 136. Die eerste reël van Psalm 136 word deur die vader gesing en die tweede deel deur die huisgesin as refrein. Die fees word afgesluit met die drink van die vierde beker en dan bly die gesin die nag bymekaar met verdere sang en vertellings.

Die Eksodusverhaal van die Pasgaseremonie onthul belangrike feite. Die Pasga was eerstens 'n gemeenskaplike maaltyd met die klem op huisgesinne. Tweedens het die bloed van die lam die volk van God onderskei van diegene wat buite die verbond was. Derdens sluit die Pasga die offer en die maaltyd in. Die slag van die lam maak dit 'n offer en die eet van die lam maak dié wat die lam eet deelnemers aan die offer. Die pasga is vierdens 'n gedenkmaaltyd; 'n fees waartydens God se magtige dade van verlossing onthou moet word. Vyfdens sal die toekomstige geslagte die Pasga nie net as ' $n$ herinnering aan ' $n$ handeling van God in die verlede sien nie. "Their dramatic reenactment of it illustrates their ongoing participation in this decisive act of redemption." (Mathison, 2002:188.)

\subsection{Die instelling van die nagmaal tydens die betrokke Pasga}

By die instelling van die nagmaal sluit Jesus net by twee momente uit die Paasmaaltyd aan, naamlik die moment van die breek van die brood na die rondgaan van die tweede beker asook die moment van die seën en rondstuur van die derde beker, die beker van danksegging of van lofprysing. Dit is opmerklik dat Jesus nie by die baie ander handelings wat tydens die Pasga plaasgevind het, aangesluit het nie. Die mees opvallende is dat Hy hoegenaamd nie by die moment van die eet van die paaslam aangesluit het nie. Die sentrale figuur in die Pasga was die paaslam en dit ontbreek heeltemal in die 
nagmaal (Morris, 1993:100). Om hierdie rede is die nagmaal beslis nie 'n Christelike vorm van die Pasga nie.

De paasmaaltijd is niet zonder meer in het avondmaal 'overgegaan'. Het avondmaal is de vervulling van het pascha. De lijn van het pascha is niet in het avondmaal doorgetrekken, maar opgenomen. (Versteeg, 1980:34.)

Dit is duidelik dat daar kontinuïteit is, maar veral ook lyne van diskontinuïteit tussen die Pasga en die nagmaal. Die nagmaal het nuwe momente in vergelyking met die Pasga, maar is ook die vervulling van aspekte wat deur die Pasga na vore gebring is. Vir die doeleindes van die verryking van die nagmaal deur op die verhouding tussen Pasga en nagmaal te fokus, word verder op aspekte gekonsentreer waarin die Pasga en die nagmaal raakpunte het. Die twee belangrikstes is die brood- en bekerwoord.

\subsubsection{Die broodwoord}

Jesus sluit aan by die breek van die ongesuurde brood met die broodwoord: "Dit is my liggaam wat vir julle gegee word. Gebruik dit tot my gedagtenis." Die woord liggaam kan maklik verstaan word as die uiterlike en sigbare lyf van 'n persoon. In die Nuwe Testament dui liggaam eerstens die persoon in die totaliteit van sy menswees aan. Jesus se woorde beteken dus ten diepste: "Dit is Ekself." (Harrington, 2006:39.) Dit is Hy wat Homself oorgee in sy selfoorgawe aan die kruis. Hy gee Homself "vir julle" (Luk. 22:19; 1 Kor. 11:24). Dit beteken "ten behoewe van" of "in die plek van". Dit is 'n selfoorgawe in die plek van die gelowiges. "The words of the institution, 'broken for you' and 'shed for many', point to the fact that the death of Christ is a sacrificial one, for the benefit and even in the place, of His people." (Phillips, 2003:196.) Jesus is die Paaslam wat Homself vir die sonde van sy volgelinge geoffer het en dit wys heen na 'n nuwe en beter verlossing wat Hy bewerk het (Routledge, 2002:215).

Paulus beskryf die frase "brood wat ons breek" as 'n koinonia "met die liggaam van Christus" (1 Kor. 10:16). In die Pasga was die brood wat uitgedeel is 'n koinonia met al die volksgenote van Israel oor al die eeue. Hierdie koinonia met die liggaam van Christus beteken om deel te hê aan die kruisoffer van Christus, 'n doodwees vir die sonde en 'n lewe vir God (Rom. 6:11). In die nagmaal is die breek en deel van die brood 'n koinonia met die nuwe Israel in 'n nuwe eksodus (Theiss, 1994:29).

Die broodwoord kry 'n verdieping deurdat Jesus dit instel op die oomblik wanneer ten opsigte van die ongesuurde brood uitgeroep is: 
"Dit is die brood van ellende wat ons vaders in Egipte geëet het." Die brood waarvan Jesus sê dat dit sy liggaam is, was dus die brood van ellende en smarte. In Jesus se selfoorgawe kom die verlossing uit ellende tot volmaaktheid.

\subsubsection{Die bekerwoord}

Tussen die brood- en bekerwoord verloop daar 'n lang tyd, want die hoofmaaltyd word dan geëet, waarvan die paaslam die belangrikste bestanddeel was. By die bekerwoord word in al vier berigte verwys na die bloed van die Nuwe Testament (Matteus en Markus) of die Nuwe Testament in sy bloed (Lukas en Paulus). Bloed is ook die aanduiding van die totale persoon en omdat daar in die hele Skrif 'n noue verbondenheid tussen bloed en lewe is, beteken die woorde "Dit is my bloed" dat sy lewe aan die kruis wegvloei in 'n gewelddadige dood. Hierdie gedagte word aan die Nuwe Testament of Nuwe Verbond (vgl. Jer. 31:31; Eseg. 37:26) verbind. Wanneer Jesus dus by die derde beker hierdie woorde uitspreek, verwys Hy na die realisering van die nuwe verbond wat die profete in die vooruitsig gestel het. Die tyd van die nuwe verbond sou die tyd van die volkome herstel van die verhouding met die Here wees.

By die eerste Pasga open die slag van die lam en die smeer van die bloed aan die deurkosyne die weg tot God se verlossing van Israel uit Egipte en vir die verbond by Sinaï, wat die volk se identiteit vestig. Net so open die versoeningsbloed van Jesus die weg tot verlossing van die wêreld uit die slawerny van die sonde en die skep van 'n nuwe verbondsverhouding met gelowiges (Routledge, 2002: 219). Eksodus 24:8 beskryf hoe die verbondsbloed op die volk Israel gesprinkel moet word. Jesus wys op sy bloed, sy offer aan die kruis, as die merkteken van die nuwe volk van God wat in hierdie nuwe verbond mag deel.

Just as the Passover, with its sacrifice of the Paschal lamb, was a sacrament that prefigured Christ to come, so likewise once Christ has come, it is fitting that he institute a new sacrament that manifests and contains his salvific sacrifice. (Levering, 2005:13.)

Die beker met wyn is in die Ou Testament 'n teken van die lot van dié wat dit drink. Dit kan wees tot die wraak van God vir die wat buite die verbond is (Ps. 75:8; Jer. 25:15-29; Jes. 51:17, 21, 22), of dit kan wees tot seën en vreugde vir diegene wat binne die verbond is (Ps. 16:5, 6; 23:5; 116:13). Die derde beker was 'n vloek oor die nasies en 'n seën vir die volk Israel (Theiss, 1994:30). Dit is alge- 
meen aanvaar dat Jesus ná die drink van die derde beker en die uitspreek van die woorde dat Hy eers in sy koninkryk weer wyn sal drink, dadelik na Getsémane vertrek het en daar gebid het dat die lydensbeker, die beker van God se straf, by Hom moet verbygaan. Die woorde by die derde beker verwys na die vervulling van sy Koningskap wanneer Hy in heerlikheid weer sal kom (Jones, 1986: 444). Die beker word ook in 1 Korintiërs 10 die koinonia met die bloed van Christus genoem. Deur deelname aan die kruisoffer en die sterwe saam met Christus, kry die lede van die nuwe verbond deel aan die vreugde van verlossing en die nuwe verhouding met God in Christus.

Jesus spreek die bekerwoord die oomblik wat die beker van danksegging of lofprysing aangekondig word. Tydens die Pasga is dit die oomblik wanneer die feesvreugde deurbreek. Jesus se offer aan die kruis is die basis vir die vreugde van sy volk, asook die inhoud wat die vreugde verhoog. Die verhouding met God is herstel; die versoening het plaasgevind. By die broodwoord is die fokus op die brood van ellende en smart en by die bekerwoord op danksegging en vreugde.

Zo word deur die broodwoord aangegeven waarvan de gelovigen verlost zijn: de ellende van de dood door de zonde ... . Zo word door de bekerwoord aangegeven waartoe de gelovigen verlost zijn: de vreugde van het leven in het nieuwe verbond. (Versteeg, 1980:50.)

\subsubsection{Die aankondiging van 'n nuwe begin}

Die nagmaal vervul die Pasga asook die Fees van die Ongesuurde Brood. Die Fees van die Ongesuurde Brood volg regstreeks na die Pasga vir sewe opeenvolgende dae. Tydens hierdie periode moet die ou suurdeeg verwyder word en ongesuurde brood geëet word. $\mathrm{Na}$ die eerste Pasga het die eksodus begin en is die volk bevry; ' $\mathrm{n}$ nuwe begin het aangebreek (Coutsoumpos, 2005:8). Die verlede moet nou agterlaat word. Paulus (1 Kor. 5:7-8) neem in die Nuwe Testament die gedagte van die ongesuurde brood op. Deur die dood en opstanding van Christus breek daar vir Christene 'n beslissende nuwe begin in Christus aan. Die ou suurdeeg van onsedelikheid en ander sonde (kakia en ponhria, twee woorde wat elke soort "sonde" insluit) moet weggeneem word en met die ongesuurde brood van reinheid en waarheid vervang word.

The Passover idea of 'leaven', then, is one of decisive newness: the old has passed away and all things have become new. (Motyer, 2005:131.) 
Because the definite Passover Lamb has been sacrified, we are in a perpetual feast of Unleaven Bread, continually cutting of the old leaven. In Christ, there has been a new and even greater exodus, which we celebrate at his table. (Leithart, 2000:100.)

Die Pasga was van so 'n groot betekenis vir Israel dat die jaarlikse herdenking daarvan beskerm moes word sodat dit nie slegs 'n verbygaande en eenmalige herinnering per jaar is nie. Die Fees van die Ongesuurde Brood volg dus op die Pasga. Hierdie besondere sewe dae met 'n unieke diëet en nog verdere offers, moes die herinnering aan die eksodus as 'n lewensveranderende gebeurtenis laat insink sodat dit 'n voortdurende effek op die lewenspatroon van die volk kon hê. Die beslissende gebeure van die dood en opstanding van Christus moet des te meer deur die gereelde viering van die nagmaal 'n nuwe lewenspatroon by die deelnemers aan die maaltyd van die Here tot stand bring (Motyer, 2005:150). Die nuwe lewenspatroon sluit 'n "wandel met God", 'n lewe in gemeenskap met die lewende Christus in.

'n Belangrike afleiding uit Eksodus 12 is dat die Pasga 'n nuwe begin vir die volk is en dat dit nooit vergeet mag word nie (Eks. 12:2, 14). In Eksodus 12:2 word 'n radikaal nuwe kalender aangekondig: 'n ander maand word nou die eerste maand van die jaar. Die nuwe begin wat hierdeur vir die volk geskep is, begin met die dood van die Paaslam. "This represents a much wider reorientation of life itself, for Israel's existence as a nation began all over again and in a fresh and wonderful way when the lamb died." (Motyer, 2005:130.) Die dood van Christus was 'n beslissende ingryping wat gelowiges van vernietiging en sonde bevry en hulle in 'n nuwe manier van lewe inlei wat hulle voortaan as volk van God karakteriseer (Morris, 1993:103). Deur die instelling van die nagmaal maak Jesus bekend dat in en deur Hom 'n nuwe Eksodus begin het (Mathison, 2002: 235).

\subsubsection{Die gemeenskaplike aspekte van gedenk (herinner, onthou) en van verkondig}

In bybelse sin is herinnering (gedenk) baie meer as 'n nadinkoefening. Dit is in werklikheid die belewing van die hede van dit wat gedenk moet word (Jones, 1986:434). So belangrik is hierdie aktiwiteit dat, behalwe die gedenk rondom die Pasgafees, die enigste ander aanduiding van voortgaande herinnering (herdenking) die Naam van die Here was (Eks. 3:15). Die gedenk van die bevryding moes die nuwe begin so sterk bevestig dat dit nooit weer vergeet sal 
word nie. Vir altyd en vir elke nuwe geslag sal nie alleen die begin van die nuwe jaar nie, maar ook die afsondering van die veertiende dag as feesdag (Eks. 12:14), hulle daaraan herinner om die Pasga te onderhou (Motyer, 2005:146). Net so koppel Jesus by die instelling van die nagmaal die gedenk aan die lewe van die nuwe volk en word dit 'n sentrale verlossingsfeit wat nooit vervang kan word nie (Motyer, 2005:147). Die deelnemer aan die nagmaal eet en drink tot Jesus se gedagtenis wanneer hulle vandag in elkeen se unieke situasie hulle met hulle hele lewe verlaat op die verlossende handeling van God, soos dit in sy volheid in die verlossingsgebeure aan die kruis geopenbaar is. Nagmaalviering is nie bloot 'n saak van die verstand nie, maar van die hele lewe (Routledge, 2002:217).

Die "Pasga-gedenk" handel oor die verbond tussen God en die volk. Dit gaan oor God se "onthou" en "herinner", maar ook oor die volk se "onthou" en "herinner". In hierdie sin hou die nagmaal die belofte in dat God sy Seun se versoeningswerk nooit sal vergeet nie en dat sy Seun in sy pleit vir sy volk die Vader sal "herinner" aan sy werk in ons plek. Net so sal ons, as deelgenote aan hierdie verbond, herinner word deur die opdrag om te "gedenk" en te "glo" (McKenna, 2005:506).

In die Pasga word gedink aan die eksterne lyding, smarte, eksterne gevaar en die bewaring in die omstandighede van angs en die bevryding daarvan. Hulle moes haastig vertrek weens die eksterne gevaar wat hulle bedreig het. In die nagmaal word ook op lyding en gevaar van mense gefokus. Die nagmaal is gekoppel aan die lewe, lyding en dood van Jesus. Die nagmaal is ingestel in die nag waarin Jesus oorgelewer is aan die magte van hierdie wêreld. Hier is egter 'n beslissende verskil tussen die Nagmaal en die Pasga.

The Passover meal remembers and celebrated a community bound in solidarity as it sets forth in a dangerous situation. By contrast, the Supper concentrates on a complex situation of danger not only from outside, but also from inside. (Welker, 2000:46.)

In die nagmaal moet dus ook gefokus word op die pyn en gevare wat gelowiges van binne deur hulle sonde bedreig, asook die gevare waarin hulle elke dag blootgestel is. Juis deur die viering word die eskatologiese "hoop" versterk en vandaar kry die nagmaalgebruiker krag om die gevare te hanteer.

Daar is ' $n$ duidelike parallel tussen die Pasga en die nagmaal wanneer die aspek van verkondiging onder oë geneem word. Paulus 
koppel die instelling van die nagmaal aan "die verkondiging van sy dood totdat Hy kom". In Eksodus 12:26 en 27 kom die verkondigingsaspek van die Pasga na vore deurdat die jongste kind die vraag na die betekenis van hierdie besondere Paasnag vra en die huisvader breedvoerig van die uittog vertel, op so 'n wyse dat dit 'n verkondiging van die hede is (Motyer, 2005:147). Die eet van die brood en die drink van die wyn wil by die deelnemer aan die nagmaal 'n reaksie uitlok. Dit moet 'n proklamerende belydenis wees met betrekking tot die dood (en opstanding) van Christus. Waar sodanige reaksie uitbly, ontbreek hierdie belangrike element van die nagmaal en is die nagmaalviering nie volledig nie.

\subsubsection{Die unieke aspek van verwagting in die nagmaal}

Hoewel daar in die Pasga moontlik aanduidings kan wees van 'n Messiasverwagting, is dit baie vaag. Die Pasga fokus byna in geheel op die verlede, op die gebeurtenis wat plaasgevind het toe God reddend ingegryp het deur die verlossing uit die slawerny van Egipte.

Paulus leer met krag dat deelname aan die nagmaal ' $n$ verkondiging van die dood van die Here is.

Paul at once links Jesus' death, not with his resurrection, ascension and enthronement in heaven, but with his return, for the proclamation is, 'until he comes'. (Motyer, 2005:147.)

Die maaltyd van die Here sal sy volkome vervulling vind wanneer die Here self met sy volk saamkom en die hemelse maaltyd voorsien in gemeenskap met die Vader (Coutsoumpos, 2005:124).

Die nagmaal kan dus in teenstelling met die Pasga, in drie tydsdimensies verklaar word. Dit wys terug na die versoeningsdood van Jesus; dit versterk en laat die persoonlike verhouding met Christus in die hede beleef word; en dit verwag die wederkoms van Christus in die toekoms (Leithart, 2000:158).

\section{Aspekte wat in 'n aanvullende formulier aandag kan kry}

Dit wat by die besondere Pasga wat Jesus en sy dissipels gevier het, gebeur het en gesê is, is ook tot 'n groot mate bepalend vir die nagmaal. Die Pasga en die nagmaal stem daarin met mekaar ooreen dat dit om 'n maaltyd gaan waarin versoening met God versinnebeeld word; 'n maaltyd waarin sy verlossende optrede wat in 'n aangrypende historiese gebeurtenis plaasgevind het, gedenk word; 
en 'n maaltyd waarin gemeenskap met Hom en sy gelowiges beoefen word (Helberg, 1990:29).

- By die nagmaal is die handeling by die eet van die brood en die drink van die wyn nie identies nie. Elkeen verteenwoordig 'n besondere faset wat met die lyde en sterwe van Christus gepaard gaan en wat weer die effek van die dood van Christus in die hede na vore bring.

- By die eet van die brood van smarte dink en beleef die deelnemer aan die nagmaal die smart van die slawerny van die sonde en gee doelbewus hierdie skuld aan Christus af. Daarom kan die nagmaalgangers ook die bevryding daarvan regstreeks ontvang en vier "tot vergewing van sondes" (Matt. 26:28).

- Die versoeningsbloed open die weg tot verlossing, is die grond vir die nuwe Eksodus, skep en onderhou 'n nuwe verbondsverhouding en gee so aan almal wat aan die nagmaal deelneem 'n nuwe identiteit in Christus.

- By die drink van die beker van danksegging breek die feesvreugde deur, want Jesus se bloed, sy offer aan die kruis, is die grond en inhoud wat die vreugde en belewing van verlossing en versoening tot 'n hoogtepunt lei.

- Die broodwoord dui aan waarvan die gelowiges verlos is, naamlik die ellende van die dood deur die sonde. Die bekerwoord dui aan waartoe die gelowiges verlos is, naamlik die vreugde in die lewe van die nuwe verbond.

- Deur die dood en opstanding van Christus, wat in die nagmaal gevier word, breek 'n nuwe begin aan. Dit vra dat die lewe gesuiwer moet word van die ou sondige gewoontes (die ou suurdeeg) as die resultaat en uitwerking van die viering van die nagmaal. Dit vereis 'n nuwe lewenspatroon, lewende gemeenskap met Christus en 'n volgehoue wandel met God.

- Die bevel van Jesus om in die nagmaal sy dood te gedenk, moet die uitwerking op die nagmaaldeelnemers hê dat hulle hulle hele lewe volgens die verlossingsgebeure aan die kruis bou en rig.

- Die nagmaal moet weens sy unieke eskatologiese perspektief (in teenstelling met die Pasga), die uitwerking hê dat die dood van Christus, deur die viering in die erediens en veral ook deur die viering in die daaglikse lewe, verkondig word totdat Hy kom. 


\section{5. 'n Poging tot 'n aanvullende formulier gefokus op die verhouding tussen Pasga en nagmaal}

\section{Nagmaalformulier gefokus op die vervulling van die Pasga}

\section{Instelling:}

"Die dag van die ongesuurde brood, waarop die paaslam geslag moes word, het aangebreek. Jesus stuur toe vir Petrus en Johannes vooruit met die opdrag: 'Gaan berei die paasmaaltyd vir ons voor dat ons dit kan eet.' Hulle het gegaan en dit gekry net soos Jesus vir hulle gesê het, en die paasmaaltyd voorberei. Toe dit tyd was, het Jesus aan die tafel gegaan en die apostels saam met Hom. Hy sê toe vir hulle: 'Ek het baie daarna uitgesien om hierdie paasmaaltyd saam met julle te eet voordat Ek ly. Ek sê vir julle: Ek sal dit nie weer eet voordat dit in die koninkryk van God sy volle betekenis gekry het nie.'” (Luk. 22:7, 8, 13-15.)

"En terwyl hulle eet, het Jesus brood geneem en die seën gevra. Daarna het Hy dit gebreek en vir sy dissipels gegee met die woorde: 'Neem, eet; dit is my liggaam.' Toe neem Hy 'n beker, en nadat Hy die dankgebed uitgespreek het, gee $\mathrm{Hy}$ dit vir hulle en sê: 'Drink almal daaruit, want dit is my bloed, die bloed waardeur die verbond beseël word wat vir baie vergiet word tot vergewing van sondes. Ek sê vir julle: van nou af sal ek nie weer wyn drink nie tot op die dag wanneer ek saam met julle die nuwe wyn in die koninkryk van my Vader sal drink.'" (Matt. 26:26-29.)

\section{Gedagtenis}

'n Maaltyd dra in die Bybel dikwels die karakter van die beseëling van 'n verbond (vgl. Gen. 31:46). Die paasmaaltyd was 'n fees in die teenwoordigheid van die Here en was voor en na die ballingskap meestal ' $n$ verbondsvernuwing ná die sonde en dus verbondsverbreking van die volk. Die paasmaaltyd moes soos die ander feeste 'n vrolike fees wees, want daarmee vier die volk die verlossing en bevryding uit die slawerny van Egipte. Verlossing word meermale aan 'n oorvloedige maaltyd van goeie kos en geurige wyn gekoppel (Jes. 25:6).

Jesus vier die laaste maaltyd voor sy sterwe deur saam met sy dissipels die paasmaaltyd te eet. Die maaltyd het begin deurdat die vader van die gesin, in hierdie geval Jesus self, die 
eerste beker vol wyn maak, die seën vra en dit uitdeel. Na die eerste beker word bitter kruie in asyn gedoop om die verdrukking van die volk te simboliseer en om daarmee te identifiseer. Die verhaal van die uittog word na aanleiding van 'n vraag van die jongste kind vertel om so die groot dade van bevryding deur God te gedenk. Nadat met die tweede beker ook soos met die eerste gehandel is, neem die vader die ongesuurde brood, breek dit en deel dit uit. Hierdie brood is die brood van smarte, die brood wat herinner aan die swaarkry in Egipte (Deut. 16:3). Dan eet die volk die eintlike paasmaaltyd: die lam wat geslag en gebraai is. Die volk word so herinner aan die bloed van die lam wat hulle geëet het aan die deurkosyne, wat die doodsengel by hulle huise laat verbygaan het. Dan breek die oomblik aan waarop die derde beker, naamlik die beker van danksegging en lofprysing, rondgegee word. Dit simboliseer die oomblik waarop vreugde na die eet van die paaslam deurbreek en God gedank word vir die heerlike bevryding, sy genade, goedheid en liefde. Die gesin sing dan die paaspsalms, die Pasga-hallel (Ps. 113-118) en dit loop uit op die groot lofprysing van Psalm 136. Die paasmaaltyd word met 'n vierde beker wyn afgesluit.

Jesus sluit met die instelling van die nagmaal by net twee elemente aan: by die breek van die ongesuurde brood en by die derde beker met wyn. By die uitdeel van die brood sê Jesus: "Dit is my liggaam ..." Met liggaam sê Jesus: "Dit is Ekself in my selfoorgawe aan die kruis." Die woorde weerklink juis wanneer hulle die brood van smarte, die brood wat aan ellende laat dink, ontvang en eet. In Jesus se liggaam, in sy volle Persoon, kom die verlossing uit die allergrootste ellende. $\mathrm{Hy}$ is die Lam wat die sonde van die wêreld wegneem. Hy neem plaasvervangend die sonde en skuld van die gelowiges op Hom. Jesus sluit aan by die derde beker wyn wanneer Hy verklaar: "Dit is my bloed, die bloed waardeur die verbond verseël word." Met bloed dui Jesus aan dat sy lewe wegvloei in 'n geweldadige dood. Hy bedoel met die frase "Dit is my bloed ..." dat dit Hyself is in sy geweldadige dood. Jesus is die ware Paaslam (1 Kor. 5:7). Sy offer is die vervulling van die offer van die paaslam, asook die vervulling van al die Ou-Testamentiese offers. Sy verbondsbloed is 'n verwysing na Eksodus 24:8 waar vertel word dat die verbondsbloed op die volk gesprinkel moes word by die sluiting van die verbond by Sinaï. Jesus se bloed is die unieke merkteken van sy nuwe volk wat in die nuwe verbond mag deel. Die derde beker wyn was die 
beker van danksegging en vreugde, die aanbreek van 'n nuwe tyd. In Jesus se selfoorgawe aan die kruis word die nuwe verbond gesluit en breek die nuwe tyd van verlossing aan.

In die broodwoord word aangedui waarvan die gelowiges verlos word, naamlik die ellende van die dood deur die sonde. In die bekerwoord word geleer waartoe die gelowiges verlos is: die vreugde van die lewe in die nuwe verbond.

\section{Gemeenskap}

Om ten volle deel te kry aan die bevryding van ellende en die vreugde van verlossing moet ons Christus in die geloof omhels. Soos tydens die bevryding uit Egipte 'n geloofsdaad in die besprenkeling van die deurkosyne gevra is, so moet ons nou Christus en sy weldade in die geloof toeëien. Dit kom deur die daad waar ons ons harte na Christus in die hemel verhef en sodoende met Hom in gemeenskap kom. By die broodwoord en die uitdeling van die brood moet ons biddende ons smet, skuld, sonde, bekommernis en hartseer aan Christus afgee. Tegelyk kan ons daarvan verseker wees dat Christus dit finaal sal wegdra en deur sy vergewing uitwis. By die woorde oor die beker wyn en die drink van die wyn moet ons in gemeenskap met Christus vol vreugde Homself en sy weldade toeëien, naamlik vergewing van sonde, geregtigheid en heiligheid. Christus is tegelyk die Gawe en die Gasheer van die nagmaal.

Omdat ons as geloofsgemeenskap dieselfde voedsel, naamlik brood en wyn inneem en die geestelike voedsel, naamlik Christus, toeëien, het ons ook innige gemeenskap met mekaar. Ons deel aan dieselfde nuwe lewe, is ingesluit in die nuwe verbond en beleef dieselfde vreugde. Ons kan daarom die gawes van die nuwe verbond, byvoorbeeld liefde, meelewing en mededeelsaamheid aan mekaar en aan ander deurgee.

\section{Selfondersoek}

Die Pasga het dikwels op bekering, lewensvernuwing en verbintenisse tot 'n nuwe verhouding met die Here gevolg. In die selfondersoek moet ons ook hierop fokus. Ons behoort in die raamwerk van die verbond selfondersoek te doen na ons persoonlike verhouding met Jesus Christus, die Lam van God. 


\section{Opwekking en uitnodiging}

Om dan nou ons ellende, sonde, skuld en swaarkry aan die ware hemelse Brood, Christus, af te gee en Homself, sy geregtigheid, verlossing uit ellende, die vergewing van sonde en ewige vreugde van die ware Paaslam toe te eien, laat ons ons harte ophef na die hemel waar Jesus Christus nou regeer. Hy voed ons in hierdie maaltyd deur die werking van die Heilige Gees sodat ons swaarkry en vreugde kan hanteer totdat Hy in heerlikheid weer kom.

\section{Viering}

Die brood van smarte wat ons breek, is die gemeenskap met die liggaam van Christus. Hy beveel: "Neem, eet; dit is my liggaam."

Die beker wyn van lofprysing wat ons met danksegging seën, is die gemeenskap met die bloed van Christus. Hy beveel: "Drink almal daaruit, want dit is my bloed, die bloed waardeur die verbond beseël word en wat vir baie vergiet word tot vergewing van sondes."

\section{Danksegging}

Laat ons die Here loof en prys vir sy Seun. Christus het die ellende van ons sonde en ewige straf weggeneem en aan ons die vreugde van verlossing en die ewige lewe gegee. Laat ons Hom prys met die woorde van die lof in die liedere by die Paasfees:

- Die Naam van die Here moet geloof word nou en vir altyd (Ps. 113:2).

- Aan die Naam van die Here kom die eer toe, want dit is $U$ wat liefde en trou bewys (Ps. 115:1).

- $\quad$ Ek het die Here lief. Ek wil U loof met 'n dankoffer, ek wil die Naam van die Here aanroep (Ps. 116:1, 17).

- $\quad$ Prys die Here alle nasies, loof Hom alle volke (Ps. 117:1).

- $\quad U$ is my God, $U$ wil ek loof; my God u grootheid wil ek besing (Ps. 118:28).

- Loof die Here want Hy is goed. Aan sy liefde is daar geen einde nie (Ps. 136:1). 


\section{Dankgebed}

Here, ons God, ons dank $U$ met ons hele hart dat ons hierdie maaltyd, wat ons Here Jesus ingestel het, kon geniet en dat ons met die Lewende Christus gemeenskap kon hê. Ons dank $U$ dat ons, bevry van ons ellende, sonde en skuld ons nuwe lewe met blydskap kan voortsit. Ons is verseker dat ons in 'n nuwe verbond, 'n nuwe verhouding met $U$, deur ons Middelaar, Jesus Christus, lewe. Ons bid dat $U$ deur u Heilige Gees ons ook in ons lewe van elke dag in staat sal stel om deur innige gemeenskap met Christus ons sonde te kan besef, te kan bely en te kan aflê, en dat ons telkens met blydskap in heiligmaking kan groei sodat ons al meer die beeld van Christus in die wêreld kan vertoon. Gee ons die genade om met vrymoedigheid die dood van ons Here te verkondig op elke terrein van ons lewe. Gee ons in die pyn en swaarkry van hierdie lewe, die perspektief en hoop op die lewe by U. Ons bid: Kom Here Jesus, kom gou! Ons loof $U$ want $U$ is goed. Aan $u$ liefde is daar geen einde nie. Amen.

\section{Geraadpleegde bronne}

BRIENEN, T 1987. De liturgie bij Johannes Calvijn: zijn publicaties en zijn visies. Kampen: De Groot Goudriaan.

BRUMBERG-KRAUS, J. 1999. "Not by bread alone ...": the ritualisation of food and table talk in the Passover seder and in the Last Supper. Semeia, $86: 165-182$.

CALVIN, J. 1959. The Gospel according to St John 1-10. Trans. by T.H.L. Parker. Grand Rapids: Eerdmans. (Calvin's commentaries.)

COUTSOUMPOS, P. 2005. Paul and the Lord's Supper: a socio-historical investigation. New York: Peter Lang.

DE KLERK, B.J. 1990. Die persoonlike geloofsdaad van die nagmaalsgebruiker. Koers, 55(1):163-178.

DORN, C. 2007. The Lord's Supper in the Reformed Church in America: tradition in transformation. New York: Peter Lang.

GREEN, J.B. 1999. Preparation for the Passover (Luke 22:7-13): a question of redactional technique. (In Orton, D.E., ed. The composition of Luke's Gospel: selected studies from Novum Testamentum. Leiden: Brill. p. 157166.)

HARRINGTON, D.J. 2006. The Paschal mystery. America, 194(9):39-40.

HELBERG, J.L. 1990. Die Pasga in die nagmaal. Koers, 55(1):17-31.

JONES, R.C. 1986. The Lord's Supper and the concept of anamnesis. Word and world, 6(4):434-445.

LANG, B. 2008. Hebrew life and literature: selected essays of Bernard Lang. Surrey: Ashgate.

LEITHART, P.J. 2000. Blessed are the hungry: meditations on the Lord's Supper. Moscow: Canon. 
LEVERING, M.W. 2005. Sacrifice and community: Jewish offering and Christian Eucharist. Oxford: Blackwell.

MATHISON, K.A. 2002. Given for you: Reclaiming Calvin's doctrine of the Lord's Supper. Phillipsburg: P \& R.

MAZZA, E. 1999. The celebration of the Eucharist: the origin of the rite and the development of its interpretation. Collegeville: Liturgical Press.

McKENNA, J.H. 2005. Eucharist and memorial. Worship, 79(6):504-522.

MORRIS, L. 1983. The atonement: its meaning and significance. Leicester: InterVarsity.

MOTYER, A. 2005. The message of Exodus. Leicester: InterVarsity. (The Bible speaks today.)

PHILLIPS, D 2003. The Lord's Supper: an overview. (In Ryken, P.G., Thomas, D.W.H. \& Duncan III, J.L., eds. Give praize to God. Phillipsburg: P \& R. p. 193-121.)

ROUTLEDGE, R.L. 2002. Passover and Last Supper. Tyndale bulletin, 53(2):203-221.

SEGAL, J.B. 1963. The Hebrew Passover: from the earliest times to AD 70 . London: Oxford University Press.

SIMPSON, H.W. 1981. Calvyn se kategismus. Potchefstroom: Potchefstroomse Teologiese Publikasies.

THEISS, N. 1994. The Passover feast of the new covenant. Interpretation, 48:17-35.

VERSTEEG, J.P. 1980. Het avondmaal volgens het Nieuwe Testament. (In Van 't Spyker, W., Balke, W., Exalto, K. \& Van Driel, L., eds. Bij brood en beker. Kampen: De Groot Goudriaan. p. 9-64.)

WANDEL, L.P. 2006. The Eucharist in the reformation: incarnation and liturgy. Cambridge: Cambridge University Press.

WELKER, M. 2000. What happens in Holy Communion. Trans. by J.F. Hoffmeyer. Grand Rapids : Eerdmans.

WITVLIET, J.D. 2003. Worship seeking understanding: windows into Christian practice. Grand Rapids: Baker.

\section{Kernbegrippe:}

beker, drink van die

brood, eet van die

formulier, aanvullende

nagmaal

Pasga

verbond

\section{Key words:}

bread, eating of the

covenant

cup, drinking of the

formula, supplementary

Lord's Supper

Pascha 